American Journal of Qualitative Research

June 2021, Vol. 5 No. 1, pp. 67-84

https://doi.org/10.29333/ajqr/10793

(C) 2021 AJQR. http://www.ajqr.org
AMERIGAN

JOURNAL OF QUALTATIVE

RESEARCH

ISSN: $2576-2141$

\title{
Turning Collective Digital Stories of the First-year Transition to College into a Web of Belonging
}

\author{
Mery F. Diaz ${ }^{1}$ \\ New York City College of Technology of the City University of New York, USA \\ Sandra Cheng \\ New York City College of Technology of the City University of New York, USA \\ Karen Goodlad \\ New York City College of Technology of the City University of New York, USA \\ Jennifer Sears \\ New York City College of Technology of the City University of New York, USA \\ Phil Kreniske \\ HIV Center for Clinical and Behavioral Studies at the New York State Psychiatric Institute and \\ Columbia University, USA \\ Ashwin Satyanarayana \\ New York City College of Technology of the City University of New York, USA
}

\begin{abstract}
In this article, we present lessons learned from "Our Stories," a digital writing project designed to assist students in the transition from high school to college. From the collective digital narratives of first-year and first-generation students at an urban public college, who are primarily Black, Indigenous, and People of Color (BIPOC), low-income, and immigrant, and who participated in a First-year Learning Communities course, we examine the challenges of becoming a college student at a public college. Further, we explore how digital writing supports community-building and influences students' transition experience, in particular, making sense of shared challenges. For these BIPOC students, the act of reflecting and writing about their college transition fostered individual and collective awareness and a sense of belonging as they began to negotiate college life. Their narratives also highlight the need for social justice pedagogies that are responsive to student experiences, use asset-based approaches, build community, and promote the active role of students in shaping their educational experiences.
\end{abstract}

KEYWORDS: BIPOC Students, Digital Narratives, First-Year College Experience, Public University, Social Justice Pedagogies.

\footnotetext{
${ }^{1}$ Correspondent Author E-mail: mdiaz@citytech.cuny.edu
} 
In this paper, we discuss the impact of an ongoing digital writing project that is grounded in responsive practices and is designed to support first-year students at an American urban public college. First, we demonstrate how students used a digital reflective writing activity to develop personal and collective narratives that explored their transition to college. Then we examine student narratives to explore the challenges of becoming a college student. Finally, we consider how this approach fits within a social justice pedagogical framework that centers on the first-year experiences of historically minoritized and marginalized students at our college.

The transition to college presents a period of adjustment for first-year students, but research shows that this is a particularly precarious time for students who are Black, Indigenous, and People of Color (BIPOC), students from low-income households, first-generation, immigrant, and language minoritized students (Acevedo-Gil \& Zerquera, 2016; Bicer et al. 2020; Brooms, 2020; Everett, 2017; Garcia, 2019; Goodlad, et al., 2019; Rodriguez et al., 2000; Tinto, 2012). Before reaching college, BIPOC students in the United States have experienced deep racial and economic inequities throughout their educational trajectory. And while more BIPOC students are attending college than ever before, the opportunity gap remains. Higher education institutions have not been designed to meet the needs of historically marginalized students for whom the new academic pressures of college, the push toward independence, and the push to develop a new set of coping skills, social skills, and overall life skills within a competitive environment are compounded (Arbona \& Jimenez, 2014; Baum \& Flores, 2011, Garcia, 2019). Thus, higher education institutions do not adequately, retain, support-BIPOC students. These students still enter and graduate from college at lower rates than White peers (NCES,2020).

Understanding the types of institutions that BIPOC students in the US attend is also relevant. Black and Latinx students, in particular, tend to rely heavily upon public institutions for higher education. In the United States, public universities where retention and graduation rates fall behind those of private universities (NCES, 2020), are institutions negatively impacted by decades of disinvestment (Alexander, 2019; Fabricant \& Briers, 2016). At the same time, evidence suggests that students who attend more selective institutions are more likely to complete degree requirements than those who attend less selective institutions (Bowen, et al., 2009). Yet, the dominant narratives defining college success still center deficit models that frame students as deficient instead of centering on BIPOC student voices and how they view themselves, the assets they bring to their college experience, and how they negotiate the demands of college within the context of neoliberal austerity (Brooms, 2020; Fabricant \& Briers, 2016, Garcia, 2019).

In this paper, we aim to center and amplify precisely those voices that have been left out of the dominant discourse on college transition. These are the voices of BIPOC students at our urban public college, their stories, and the meaning they derive from their initial experiences in our institution. As one student shares,

Well to begin with like most of you know college is nothing compared to high school. Everything is so different you become more responsible for your own things, the professors expect you to walk into class knowing how to use blackboard what is [college]first etc., but it's not like that.

Similarly, the collected stories in our digital research project capture meaningful details from the first moments of a student's college journey. These narratives uncover multiple points of adjustments during student's first weeks at the college and the institutional factors that create challenges. Further, narratives suggest that the process of writing and sharing their stories supported students as they faced the social, emotional, and bureaucratic challenges in their transition to college. Student stories offered insight into their perceptions of belonging in the 
college setting, challenges balancing school, work and family, the aspirations they held, and details about how they negotiated their new environment. Finally, the stories also evoke a broader imperative to advocate for more academic, economic, social supports in public universities, to dismantle institutional barriers, as well as the need to build on the existing research of the first-year experiences of BIPOC first-year college students.

\section{Going Digital to Foster Community for New Students}

At a four-year urban public college located on the northeast coast of the United States, a multi-year writing project provided a means for first-year students to reflect on their college experience and for faculty to better understand student needs. The potentially transformative process of writing in the student experience drove the faculty in the First-year Learning Communities (FYLC) program to develop the ongoing "Our Stories" digital writing project. Students participating in the college's learning communities were able to share their personal stories of transition from high school to college on a digital platform.

The authors of this study were faculty committed to FYLC as a high-impact educational practice, especially for those from underserved communities (Finley \& McNair, 2013; Kuh, 2008). [The College] offered a traditional learning communities' model, where students take two or more linked courses specifically designed to foster a community of learners among peers and with faculty, since 2000. Every semester, the college offers as many as fifteen learning communities, each co-developed by teams of full- and part-time faculty members. We have all instructed learning communities at the college.

We launched the "Our Stories" digital project to support student engagement and to learn about the college experience directly from our students. We believed asking students to reflect on the transition to college, sharing their triumphs and apprehensions, would expand the network of support to cultivate a stronger college community. As an urban commuter college in a major city on the northeast coast, we lacked physical space to bring students together, however, the college's unique digital platform could bring students together via a shared digital space. Specifically, the digital environment is an open-source, WordPress-based, and BuddyPress platform for teaching and learning, unique to the college (Rosen \& Smale, 2015) and used by all FYLC faculty members and students. Building on previous work by Kreniske (2017a; 2017b) and his findings on the effectiveness of reflecting on the college transition, FYLC faculty leaders adapted this model and launched the "Our Stories" project.

\section{[The College] in the Context of Higher Education in the US}

[The College] belongs to a large east-coast public university system. Our latest institutional data from the fall of 2019 show that 17,036 students were enrolled, and enrollment has grown steadily for over 12 years (New York City College of Technology, 2018). The college, located in a major city, was designated, both, a Hispanic Serving Institution and Minority Serving Institution with the majority of students identifying as Hispanic 34\%, followed by Black (non-Hispanic) $29 \%$.

Students in the college typically face a combination of economic, social, and academic needs. Approximately $61 \%$ of students lived in households with incomes of less than $\$ 30,000$ and $80 \%$ of the incoming first-year students receive some form of financial support. The college serves many students who have graduated from the city's K-12 public-school system- a highly racially and class segregated public school system where many schools are underfunded and do not have adequate resources to prepare students for higher education (American Community Survey, 2015; Ravitch, 2013; 2010). Anywhere between $53 \%-80 \%$ of students in the university system require 
some type of remediation (Gonen, 2013). Historically unmet academic needs are not the only hurdle for these students; approximately $62 \%$ of students at [the College] are the first in their families to attend college.

National trends demonstrate that colleges have been unable to retain first-year Black and Latinx students at the same rate as their White and Asian peers (Garcia, 2019; NSC Research Center, 2019). Such outcomes bring forth significant questions about equitability and the broader context of public higher education. Public universities in the United States, including ours, have experienced a steady decline of state funds for the past 40 years. Overall, tuition costs have increased by $25 \%$ - shifting a large burden of the college budget to students. At the same time, fulltime faculty positions continue to decline while the reliance on contingent faculty has continued to increase. These measures reduce access to social and academic supports for students and impact the quality of curriculum (Alexander, 2019; Fabricant \& Brier, 2016; Garcia, 2019).

Nonetheless, BIPOC students are increasingly attending college. They have aspirations and they also bring knowledge, experience, and strengths to their college journey. We embraced digital instruction, and in particular digital storytelling, because as a pedagogical tool this process presented an opportunity for students to tell their own stories and share how they navigated college as a new environment. Digital storytelling can further enable self-reflection, the building of community, and collective consciousness. Through the creation of stories, the process for meaningmaking emerges and so does the opportunity to disrupt the normative perceptions about who is a college student and what their experiences are like (Etchells, et al. 2017; Everett 2017; Rolon-Dow, 2011; Stewart \& Ivala, 2017; Vasudevan, 2006). Altogether, the potential benefits that come from digital storytelling processes are in line with research that suggests that for Black and Latinx students, peer bonding, developing and building relationships in the college community, and having access to resources are critical to ensuring their success. (Fischer, 2007).

\section{Digital 'Stories' as Social Justice Pedagogical Praxis and Method}

Through storytelling, as both, practice and narrative research method, the "Our Stories" project bears witness and lends voice to the experiences of students during their first year at [the College]. Writing and reading stories can be transformative and for this reason has been embraced across diverse disciplines such as psychology, nursing, and education (DeSalvo, 2000; Furman 2005). Because creating a story requires cognitive and affective investment, this process can lead to the narrator's self-development (Granic et al., 2020; Polkinghorne, 1988; Wertsch, 1991). The process can also help to uncover hidden stories within and among people that bring, both, increasing self-awareness, as well as the collective awareness of broader social dilemmas. In this light, using reflective writing as a pedagogical tool can serve to enable personal growth and as student stories are centered they also serve to counter dominant normative narratives about the college experience. These stories, thus, can act as a reflective and interactive vehicle with the potential for community building, the potential for mobilizing groups, and for promoting advocacy efforts (Daiute, 2014; Daiute \& Kreniske, 2016; Lambert, 2013; Lenette et al., 2015; Khran, 2019; Kreniske, 2017b).

The "narrative turn" in research emerges in the late 1970s and 80s. Increasingly adopted across various disciplines, narrative approaches stressed a shift from the dominant positivist interpretations of human phenomena toward more hermeneutic interpretations of people's experiences, about who we are, and what we have experienced (Cohler 1982; Cohler, 1991; Sandelowski, 1991; Schiff, 2014). It is this method of story construction, and meaning making from one's experiences, cultural interpretations, and the complexities of our social fabric that can be so empowering, especially for those whose truths are seldom told or included in the public 
discourse (Diaz \& Shepard, 2019). Through a narrative approach, storytelling is foregrounded, and counternarratives, in particular, can serve as compelling and powerful points of knowledge. Stories can bring forth often unheard and marginalized voices that evoke meaning and that push awareness about their lived experiences. Digital storytelling can extend these truths, the concerns of the individual and marginal groups, to wider audiences. In this manner, the "Our Stories" digital writing project considers the value of students' experiences and prior knowledge as strengths, rather than focusing on their deficits and as means for community building. The praxis of digital storytelling has been utilized as a social justice pedagogy emphasizing community-building, participatory media, emancipatory initiatives, the humanizing student experiences, and the democratizing of educational spaces (Freire, 1968; Hackman, 2005; Hantzopoulos, 2016; Lopez, 2017; Stewart \& Ivala, 2017).

Concerns over the digital divide, however, can challenge the delivery of equitable and democratized pedagogical approaches (Fabricant \& Brier, 2016; Moore et al., 2018; Reamer, 2013). The digital divide is the gap between those who have access to technology and sufficient knowledge for its utilization and those who do not. When delivered wholesale, as a means to cut costs and in place of classroom instruction, digital instruction can neglect the diverse learning and resource needs of students. Arguably, in this way, digital instruction can deepen marginalization and educational inequality for BIPOC and those from low-income backgrounds. Yet digital instructions have come a long way and research increasingly suggest that responsive practices, such as digital storytelling, can help improve writing and critical skills, promote collaboration and community, increase access to and foster faculty-student relationships, foster a sense of belonging, factors that can provide meaningful learning experiences for first-year students (Everette, 2017; Kreniske, 2017a; Purcellet al., 2013; Tinto, 2012).

\section{Implementation and Analysis}

The "Our Stories" digital writing project was designed to complement the communitybuilding efforts within learning communities' classrooms and helps extend that network beyond the physical and temporal limits of class meeting times. First-year students are guided to connect through the college-wide digital network. Over their first semester, FYLC students are also prompted with the same assignment two times; at the beginning of the semester, and in the last weeks of the semester. The project has a flexible implementation structure and allows instructors to decide how they assign "Our Stories" in their classrooms. Faculty may choose to offer extra credit, or fold the assignment into other assessments, while others make the assignment optional. Adapted from prior work on reflective writing (Walton, \& Cohen, 2011), students were asked to respond to the following prompt:

We invite you to tell a story about your first few weeks at [the College]. Research has shown that first-semester students often worry about their transition into college and how eventually students become comfortable and find a community of people with whom they are close and feel they belong. Please describe in a short story how you have experienced your first few weeks at [the College]. Aim to write 300-500 words and be sure to illustrate your post with examples from your own experiences in classes, seminars, lectures, study groups, and labs. What happened? How did you and others involved think and feel? How did it turn out? We hope this process will help you think about your transition experience. Once you 


\section{have finished writing please take time to read and comment on at least two}

of your peer's stories.

Participants in this study were students who enrolled in the college's learning community courses during the fall of 2018. Altogether there were 152 students across 11 learning communities. A total of 139 entries were posted. 98 individual students participated and wrote at least once, and 41 students responded to both prompts. Trained Peer Mentors (upper-level students) monitored and commented on the posts, and students commented on each other's posts. The posts are visible only to members of the college community who have joined the website through the college's digital platform. To protect participant confidentiality, the excerpts of student writing in this article are not attributed, although any member of the [the College] community could create a digital platform account to access these posts. With hopes of acquiring more insight into student needs, we received [the College's] Institutional Review Board (IRB) approval to analyze our students' writing responses. This article includes excerpts from students who provided consent to publish their writing.

In this study, we use a paradigmatic approach, a grounded theory analysis of the student narratives to organize and make sense of their first-year experiences (Polkinghorn, 1995; Strauss \& Corbin, 1994; Strauss \& Corbin, 1998). To triangulate the data the authors each read and re-read all student posts and took field notes focused on commonalities present across the posts. These initial notes reflect the search for broad themes that revealed key experiences that formed part of the transition to college. We shared these notes among co-authors and discussed them during a series of meetings among the authors. Subsequently, these initial impressions were consolidated, categorized, and presented during FYLC faculty development workshops. The workshop attendees included a majority of the 30 FYLC faculty members and student peer mentors. Based on the feedback from faculty and students during the workshops, we recategorized themes. Clandinin and Connelly (2000) posit that "an inquirer composing a research text looks for the patterns, narrate threads, tensions and themes within or across an individual experience and in the social setting" (p.132). Five main themes, thus, emerged from the collective stories. These themes revealed multiple aspects of first-year experiences encountered by students enrolled at an urban campus with few physical markers to distinguish the college grounds from the hustle and bustle of the city. But student's first-year experiences did not only take place within the brick and mortar but reflected the complexities of the lives they lived at home and in their communities, as well as their transnational connections. We analyzed these narratives with consideration of the social, cultural, and historical context of student's experiences (Creswell \& Poth, 2018). These five themes were, From High School to College, Fitting In, Administrative Challenges, Balancing School and Work, and Sense of Belonging.

Across these five themes, students reflected on their experiences in navigating the bureaucracy of financial aid and registration, balancing family pressures that are often unique to first-generation college students, explored concerns about connecting with others at [the College] and succeeding academically, and shared about engaging with varied teaching styles and a diverse student body. Their collective stories reveal an institution with a large immigrant population. They bring forth questions and unspoken uncertainties about legal status as documented or undocumented persons. Their writing reveals the potential of digital writing to help students take a step towards collective awareness and self-advocacy by expressing their thoughts on the challenges of their first semester in college. Finally, their writing exposes vulnerabilities and strengths, institutional barriers, and reveals how they negotiate cultural adjustments while interrogating their sense of belonging in this new academic space. The following are excerpts from 
student narratives organized across the five themes that reflect commonalities and tell the story of their transition experiences.

\section{Theme 1: From High School to College}

Student stories begin with an expected comparison to the prior schooling space they inhabited, high school. The majority of student posts comparing high school to college highlighted the differences between the two types of institutions, both physical and relational. Identity, who belongs in these educational spaces, was also a point of interrogation for many students.

Their adjustment to the physical space of the college was connected to their emotional adjustment to college life. One student described his first day at college:

While I was walking down the hall to get to my first class, I was nervous. I did not know what to expect on my first day. I walked in nervous and excited, I noticed that everything was different. No posters on the wall, no bell to indicate when the class starts and most differently no friends. High school was a place where $i$ had teachers look after me and making suren [sic] $i$ was in school every day. My first week at college made me notice that all of that was over and that if $i$ wanted help I'll have to seek for help myself.

The physical space, the appearance of college, the sounds or lack thereof indicated a stark difference to the student's experience in high school. High school offered physical and symbolic structures to support students through reminders or familiar spaces where friends congregate. The structural size of the college campus, with ten buildings scattered across several city blocks, intimidated students as they navigated their way around.

Also, the amount of students in this school is tremendous so the elevators are always packed. This puts me at a disadvantage because i try and come in on time but $i$ can't [sic] even do that since the elevators are always full except for when you don't need them.

The poor state of the elevators appeared as a common complaint among many students. Their condition brought to the forefront how the special environment, specifically [the College's] distressed facilities, impacted the student experience. In comparison to well-funded private institutions known for their attractive campuses, student observations about the physical state of the college, make salient the notions of advantages and disadvantages, survival, and competition. Students were overwhelmed by the queues,

I never knew how bad an elevator line can be until I saw [the college's] line.

Many blamed the elevators for getting to class late and recognized the lines as symptomatic of overcrowding.

The notion of time and space were also embedded in student's discovery of the cultural expectations of a new institution. The individualism of higher education replaces the collective accountability, adult control of physical space and time, and regimented structures of high school that students have grown accustomed to- factors which are particularly salient in low-income, 
under-resourced schools (Diaz, 2019; McNamee, 2016). Yet, while some students found it liberating, others expressed that the autonomy in the college experience was disconcerting. The flexibility of college schedules was experienced as frustrating. One student lamented:

There is new responsibility to get to class on time every day and the fact that the start time for class is different depending on which day it is can be disruptive.

The dawning awareness about the need for self-sufficiency on the road to college success is evident in this and other similar statements. The change from a predictable high school schedule to a heterogeneous college one, meant everyday routines, like lunch, were no longer habitual. One student wrote about skipping meals because there were no preset lunch periods, and the start times of her classes were different every day. Others found that designing their class schedule could be empowering and saw this as a benefit of college life, exclaiming

\section{I feel like I'm in control of my life and my schedule.}

The longer length of college classes was another concern for students. In contrast to the 45minute periods in high school, the college offered multi-hour sessions which demands cognitive, emotional, and physical adjustment. The switch from shorter intervals demanded extensive readjustment to learning strategies acquired and reinforced through their K-12 experience. Several students noted the big challenge of making the transition to classes that could be three hours or more in length. One student descriptively compared the adjustment to this change using terminology from video gaming.

I still haven't gotten used to sitting in the same classroom with the same teacher along with the same students for more than forty-five minutes. To transition from less than an hour to three of them with an extra thirty minutes is taking a big step. That's like changing a video game's difficulty setting from easy to extra hard while skipping every setting that is in between.

College classes also thrust younger students into learning spaces with older ones. Some students wrote that they were only one of a few new students in their courses which may have students ranging from first-year to seniors. Incoming students expressed discomfort with the diverse age range. One student wrote:

This was the day where I saw a old person in my math class. I seriously thought that old man was a teacher, but he was a student like the rest of us. It's weird being in a class with people of all age ranges.

This student, like many others, revealed an assumption about who belongs in college, expecting that everyone would be similar in age. Being one of the youngest in a classroom also added to student distress. For example, a student wrote about the discomfort with the age differences in the classroom:

I didn't like my Friday class bcus [sic] their were some old people such as moms, it made me feel nervous because I wasn't familiar with that type of 
surrounding in a class. I wasn't use to it. I was also the youngest in the class (18) everyone else was older than me.

The posts suggest the inherent diversity of a typical classroom at [the College] filled with students at different academic stages and diverse ages, was unexpected for most first-year students in the learning communities. Overall, adjusting to time, space, and expectations about routines and peers are immediate challenges in the transition.

\section{Theme 2: "Fitting In"}

As expected, new students worried about being able to connecting and finding things in common with their peers. The "Our Stories" posts revealed that many of our students belong to immigrant communities and they were concerned about fitting in socially and academically into an American university system. Immigrant students felt an increased sense of alienation from feeling foreign in already unfamiliar educational surroundings. One first-year student wrote:

Coming from a different country, I didn't know what to expect. As I walked into the building on my first day, the halls were flooded with new students, I was one of them. I thought to myself, am I dressed accordingly? Do I look worried?

The questions of belonging were repeatedly referenced in student writing. The posts expressing the concerns over "fitting in" often received replies from other students who experienced similar worries. In particular, many responses communicated support and shared solidarity as an immigrant and attempted to reassure the poster that the uncertainty of navigating new cultural experiences was a shared concern.

Posts from later in the semester showed students became more comfortable once they realized they were not alone and learned of other students from home countries. As students got to know their classmates, they learned many of their student peers were immigrants or the children of immigrants. This recognition, though, was dependent on students being exposed to and communicating with more students. This level of exchange shows the importance of students accessing and utilizing the unique platform and a project like "Our Stories." One student illustrated the importance of having access to such a place with the statement:

\section{I know more people now that I noticed some of them are from the same country, I am from.}

Student writing revealed demands unique to immigrants and children of immigrants, including transnational family obligations and how these conflict with the demands of college. This sense of obligation, and expectations for travel, came with academic repercussions. A student wrote,

My first few weeks at [the College] have been stressful. I have social anxiety, so in all my classes I mostly remained silent. Everyone else was quiet too, which made me feel better and relieved. After the first week at school, I had to go to Honduras for my sister's quinceneara during Labor Day [sic]. I caught an infection on my trip and had to miss a whole week of school (and work). 
Other experiences by immigrant students involved the stress of reading and writing in another language, especially for those who had learned English more recently. A student wrote,

I've been living in the United States for only 5 years, and I never attended school here in the U.S, so I had no idea how the education system worked, and to make it even harder on myself English is my second language.

Navigating college as a recent high school graduate, a young student, an immigrant, and a language minoritized person presented spatial, temporal, and cultural challenges. In the next section we explore how [the College's] complicated administrative processes too, are very difficult for new students.

\section{Theme 3: Administrative Challenges for Students}

The financial aid and registration process can be intimidating and frustrating for all students. "Our Stories" revealed that these difficulties were particularly troubling for students who are questioned over their legal status and their worries spill over to the impact on financial aid. One student recounted their feelings of anxiety upon receiving a letter requesting proof of status through a green card and passport. Also, if the student didn't register in a full-time capacity, financial aid could be lost or taken away. This student took several days off work to submit the required paperwork and to meet with college administrators, which ended up straining the relationship with his employer. Questioning the status of legal residency appeared to be a systemic problem that was confirmed by other students who said they received similar letters requesting documentation. The danger of receiving or losing financial aid was a stressful concern for many students.

Frustrations with paperwork (an eternal student lament) were shared by many students, who complained about long wait times for IDs or meetings with college administrators,

I would wait hours just to get service for something that would take no more than fifteen minutes.

Students were forced to make time to visit the campus to fill out requisite forms, but each visit often impacted home and work schedules. The frustration with the administrative process and wait time was palpable. One student complained with frankness,

\section{I had to come back multiple days to fill out paperwork for registration, admission, and financial aid. This sucked because I didn't know anybody and so I'd feel like a whole day was wasted every time I came in.}

Frequently, students began college life at a disadvantage because they were not aware of the administrative and academic requirements as well as available options. The lack of a central location to address advisement, registration and financial aid compounded the confusion for new students. A recent Gallup survey (2020) noted that three out of four college non-completers stated that a fragmented financial aid process impacted their academic performance. Another report noted that more than 3 million students annually who don't complete their programs of study report leaving higher education because of financial aid reasons leaving them with debt and without a degree (Tyton Partners, 2017). 


\section{Theme 4: Balancing School and Work}

Concerns over finances and being able to attend college came up frequently. Many held full-time or part-time jobs to support themselves and others while attending school. In their posts, students discussed the expenses of college beyond tuition, lamenting over expenditures for transportation, housing, and books. Managing academic- and work-related demands involved personal sacrifices and challenges. One student noted that taking care of herself was secondary to her school and work commitments. She wrote of her time consumed by school and work, which left less time for sleep and skipping meals. One student wrote:

There were two things I was extremely unexpected. Firstly, I was in trouble with the school and works' schedule. I thought three days in school would help me have a flexible time at work, so I agreed to work after school until midnight; as a result, I was so tired after work and unable coming to class on the next morning.

The challenges of attending college and working were exacerbated by the increase in academic requirements as the semester progressed. Students are exhausted as they juggle their multiple obligations. Although being able to choose courses offered flexibility in scheduling, many struggled with finding a sustainable balance between college and employment.

\section{Theme 5: A Sense of Belonging in Learning Communities}

As time went on several students shared experiences that highlighted the benefits of being in a learning community. Many believed seeing the same cohort in more than one class was the main advantage of participating in FYLC courses because the sense of community helped ease the transition to college. Seeing the familiar faces of fellow first-year students in several classes was different from their other courses with students drawn from different stages in their degree. A student wrote positively about belonging to a community of people who were all starting college,

Another thing about college is that many will be nervous on meeting new people. In fact that didn't matter to me but once I found out about my learning community classes, I was amazed on how it works too. For a whole semester I will have the same students in those LC classes. It is very nice because many of us are coming out of small high schools where we saw a lot of our friends for multiple classes.

Small high schools were part of a reform movement at the turn of the century to restructure large urban public high schools with low graduation rates, into more 'manageable' institutions, as well as the students (Noguera, 2002). Many of our students have graduated from these institutions. Participation in a learning community made the college transition less stressful and provided comfort. Another student thought their first semester felt like past school experiences and made direct reference to learning communities as the reason the transition to college life was "quick" and "comfortable." The student wrote,

My first months at [the College] didn't feel much different from high school. The reason as to why it didn't feel different from high school is because am in a learning community. This learning community helped me 
adapt to college at a fast pace because I saw familiar faces every day, so I got comfortable quickly.

One student recognized the differences between college and high school, they felt seeing the same faces in different classes provided encouragement and a level of comfort. The student wrote,

The first Learning community is something that is so beneficial to people who are introverts. Seeing the same faces in 2-3 classes made communicating more easier. ... I hope more kids take the opportunity of joining the FYLC because it really does make a difference. You get to connect with other people and not feel as timid as you would only seeing them once a week.

Finding a sense of belonging is important for incoming students and the numerous positive references to learning communities, as well as other academic support programs targeting firstyear, low-income, and first-generation college students, reflect the desire for more one-on-one connection at the college. The built-in routine of seeing the same faces across multiple classes helped construct a support network for first-year students.

\section{Reflections on the Implementation of "Our Stories"}

Implementing this project brought certain challenges that relate directly to the themes presented and limitations to access that many BIPOC students experience. Rightly, adjustments to the implementation of the project have been made every semester. Our student body is primarily BIPOC, first-generation college students, first- and second-generation immigrants, from lowincome households, and language minoritized. We are aware that some students might be concerned about their language skills and therefore apprehensive about revealing their writing to others. For some, access to technology needed for this type of project might not always be there. Still, others might have had concerns with the public format, especially if they had legal concerns such as immigration status. Nearly all students who posted about immigration-related issues refused to consent to publish their writing. Also, some faculty members expressed reluctance to participate. One reason is that this project, as it involves one to two class sessions, consumed too much valuable classroom time during a semester that already felt rushed with the demands of course curricula. And like our students, some faculty members have less familiarity and willingness to learn to navigate the college's digital platform.

As faculty and staff members who helped initiate and implement this project, we have made changes to help smooth out this process and are currently prompting student's post twice during a semester instead of the original desire for three prompts. This change was made early in the project's inception in response to student and faculty time constraints. Regarding student writing concerns, many classes now have students begin the low stakes writing assignment in class, which gives students some time to reflect on how they might compose their post. Though we encourage faculty to allow students to write spontaneously, some faculty allow students to edit or seek tutoring for help with writing their posts in a manner that they feel comfortable with presenting. We have also had faculty and staff assist students with navigating the digital platform.

One crucial aspect of this project is the requirement that students comment on their peers' posts. When this is successful, many more responses stream in, and the enthusiasm for the writing increases. Consistent commenting by peer mentors is critical to building a sense of community and 
belonging for our students on the "Our Stories" website. We also recognize the goal of community building in this project was built-in to the structure of the learning community model. As such, students may perhaps be more inclined to be responsive to peers in this type of structure. However, to make this project more successful, a better way to encourage and manage responses between students is one element we hope to develop.

\section{The Importance of Documenting Student Stories}

Our Stories" is a developing digital project that is continually assessed in hopes of making it more impactful for our students and easier for faculty to implement. As a praxis, the digital writing project is a social justice pedagogical project that centers student voices in the construction of their stories. Writing also provides space for students to reflect and shape their experiences. This study suggests that digital writing project provides an opportunity for BIPOC students to reflect on their high school to college transition, helps identify the factors complicating and supporting the student experience, and supports making connections with others as they navigate college during the first year. Furthermore, engaging student narratives of educational experiences help to contextualizes their lived experiences, the institutional complexities and challenges they come up against, and the knowledge and cultural strategies that they employ at different junctures of their first-year transition. Centering the experiences of historically minoritized and marginalized students at our college aligns with social justice pedagogical framework (Freire, 1968; Hackman, 2005; Hantzopoulos, 2016; Lopez, 2017; Stewart \& Ivala, 2017).

For our students, five major themes emerged from their collected narratives: From High School to College, Fitting In, Administrative Challenges, Balancing School and Work, and Sense of Belonging. The themes illustrated more about how BIPOC students experience and negotiate their first semester at a public university, and how they connect virtually. We consider their experiences at the college as part of an educational trajectory that has pushed many of our students to the margins due to limited resources, but also because higher education institutions are slow to recognize and build on the assets of marginalized students. Three main takeaways came through from student stories:

- As students leave high school, many from smaller settings, and enter a large diverse higher education institution, they are concerned about succeeding in little and big ways. Students need support to understand the expectations of college, and opportunities to belong and make connections. In our study, learning communities provided those opportunities to build connections and the familiarity students were seeking. Adopting pedagogical models that engender supportive communities, such as first-year clusters, learning communities, and digital platforms can be instrumental during this period of transition (Ribera, Miller \& Dumford, 2017).

- Many students struggled to navigate the bureaucratic web of financial aid and to balance work and school demands. Data suggests that dismantling bureaucratic financial aid roadblocks, and instead building student-centered financial aid process can improve retention by demystifying and increasing access (Gallup, 2020).

- Many students came from immigrant, working-class backgrounds, and spoke minoritized languages. Yet, students were initially unaware of others with similar backgrounds and experiences. Fostering a sense of belonging within and outside of the classroom seems critical for institutions that serve minoritized students. A more inclusive environment looks like institutions that embrace diverse experiences and languages, curriculum that reflects 
student's identities and experiences, faculty who mirror the student body, and when cultural diversity is celebrated (Garcia, 2019). Additionally, institutions must begin to view student's backgrounds as assets from which to build upon and cultivate, and in turn for students to see themselves reflected in the institutions they attend.

In the US, BIPOC, immigrant and working-class students are attending colleges at increasing rates. These students rely heavily on public institutions that are at the same time experiencing increased divestments, and as such struggle to adapt to meet student needs. Our study has helped us gain insight into how students reflect on their progress and make meaning from the arc of their first-semester experience. The "Our Stories" digital project has also proved a meaningful tool to give voice to first-year students, highlighting their assets and vulnerabilities, providing space for peer support, as well as how institutional practices can both contribute to challenges, and how they can work toward supporting students. As instructors, reading students' stories and hearing their voices has helped us identify in real-time diverse levels of support needed for our students as they transition to becoming college students. The voices in these stories highlight the urgency for advocacy, and the need to increase funding to develop innovative programs that support the academic, economic, and social-cultural needs of incoming students, in particular the needs of students from minoritized groups who heavily rely on public institutions for higher education. More broadly, digital reflective writing can provide colleges, within and outside of the US, with diverse and immigrant student bodies, and students who have been historically marginalized and pushed out of higher education institutions, opportunities to understand the transition experiences of their first-year students, support building connections during their first year, and build on their strengths.

As we continue with this project, we also consider the impact of the Covid-19 pandemic which has magnified the need to understand how student interactions and overall, first-year experiences have been and are being recontextualized in distance learning and virtual delivery of student supports. At the time of this writing, the US is on track to enter a deep economic recession and to lose over half a million lives to the virus. These crises have disproportionately devastated BIPOC communities and most certainly the students struggling to continue with goals of attending and completing college. The college has been almost completely online for instruction and support services since the Spring of 2020. At the same time, almost 3000 contingent faculty have been laidoff from the university system in anticipation of budget deficits. Moreover, social movements such as Black Lives Matter, and global protests have elevated the focus on the deeply entrenched and systemic problem of white supremacy, pressing the need for interrogating all levels of practice and proactively implementing anti-racist ones. The impact of the pandemic, economic uncertainty, and white supremacy are arguably global concerns. The living and learning experiences of our students will have undoubtedly been transformed and this moment of social, economic, and public health crisis requires us to help create meaningful teaching and learning practices, and institutional changes the provide supportive experiences and connectedness for our most vulnerable students.

\section{References}

Acevedo-Gil, N., \& Zerquera, D. D. (2016). Community college first-year experience programs: Examining student access, experience, and success from the student perspective. New Directions for Community Colleges, (175), 71-82. 10.1002/cc.20213

Alexander, F. K. (2019). The reality of state public disinvestment in higher education. Inside Higher Ed. https://www.insidehighered.com/views/2019/11/26/recent-studies-statedisinvestment-public-higher-education-are-misleading-opinion 
American Community Survey. (2015). Press release. https://www.census.gov/programssurveys/acs/news/data-releases/2015/release.html.

Arbona, C., \& Jimenez, C. (2014). Minority stress, ethnic identity, and depression among latino/a college students. Journal of Counseling Psychology, 61(1), 162-168. 10.1037/a0034914

Baum, S., \& Flores, S. M. (2011). Higher education and children in immigrant families. The Future of Children, 21(1). 171-193. 10.1353/foc.2011.0000

Bicer, A., Lee, Y., \& Perihan, C. (2020). Inclusive STEM High School Factors Influencing Ethnic Minority Students' STEM Preparation. Journal of Ethnic and Cultural Studies, 7(2), 147172.

Bowen, W., Chingos, M., \& McPherson, M. (2009). Crossing the finish line: completing college at America's public universities. Princeton University Press.

Brooms, D. R. (2019). "It's the person, but then the environment, too" black and latino male narratives about their college success. Sociology of Race and Ethnicity, 6(2), 195-208. $10.1177 / 2332649219884339$

Campus Logic \& Gallup. (2020). Leveling up for student financial success: student sentiment regarding financial decisions in higher education. http://go.campuslogic.com/sfs-gallupreport.

Clandinin, D. J., \& Connelly F. M. (2000). Narrative Inquiry - Experience and Story in Qualitative Research. Jossey-Bass.

Cohler, B. J. (1982). Personal narrative and the life course. In P. Baltes \& O.G. Brim (Eds.), Life Span Development and Behavior (Vol 4, pp. 205-441). New York: Academic Press.

Cohler, B. J. (1991). The life story and the study of resilience and response to adversity. Journal of Narrative and Life History, 1(2-3), 169-200.

Creswell, J. \& Poth, C.N. (2018). Qualitative inquiry and research design: Choosing among five approaches (4th ed.). Sage

Daiute, C. (2014). Narrative inquiry: A dynamic approach. SAGE Publications.

Daiute, C. \& Kreniske, P. (2016). Hopes, misunderstandings and possibilities of narrating for inclusive education. In A. Surian (Ed.), Proceedings of open spaces for interaction and learning diversities. Sense Publishers.

DeSalvo, L. (2000). Writing as a way of healing: How telling stories transforms our lives. Boston, MA: Beacon Press.

Diaz, M. (2019). Finding justice: Transforming schools with the children we serve. In M. Diaz \& B. Shepard (Eds.), Narrating practice with children and adolescents (pp. 149-170). Columbia University Press.

Diaz, M. F., \& Shepard, B. (Eds.). (2019). Narrating Practice with Children and Adolescents. Columbia University Press.

Etchells, M. J., Deuermeyer, E., Liles, V. M., Meister, S. M., Suarez, M. I., \& Chalklen, W. L. (2017). White male privilege: An intersectional deconstruction. Journal of Ethnic and Cultural Studies, 4(2), 13.

Everett, C. M. (2017). Fostering student engagement and well-being through visual narrative. Studies in Higher Education, 42, 4, 623-635. 10.1080/03075079.2015.1064387

Fabricant, M., \& Brier, S. (2016). Austerity Blues. Johns Hopkins University Press Books.

Finley, A. \& McNair, T. (2013). Report: Assessing underserved students' engagement in high impact practices. With an assessing equity in high-impact practices toolkit. Association of American Colleges and Associations

Fischer, Mary J. (2007). Settling into campus life: differences by race/ethnicity in college involvement and outcomes. The Journal of Higher Education 78(2):125-61.

Freire, P. (1968). Pedagogy of the Oppressed. Herder and Herder. 
Furman, R. (2005). Using poetry and written exercises to teach empathy. Journal of Poetry Therapy, 18(2), 103-110.

Garcia, G. (2019). Becoming a Hispanic-Serving Institution: Opportunities for Colleges and Universities. John Hopkins University Press.

Gonen, Y. (2013, March). Nearly $80 \%$ of city public high-school grads at CUNY community colleges require remediation for English or math. The New York Post. https://nypost.com/2013/03/07/nearly-80-of-city-public-high-school-grads-at-cunycommunity-colleges-require-remediation-for-english-or-math/.

Goodlad, K., Cheng, S., Sears, J., Diaz, M., Satyanarayana, A., Kreniske, P. (2019). “Our stories”: first-year learning communities students' reflections on the transition to college. Learning Communities Research and Practice, 7(2), Article 5. Available at: https://washingtoncenter.evergreen.edu/lcrpjournal/vol7/iss2/5

Granic, I., Morita. H. \& Scholten, H. (2020). Beyond screen time: identity development in the digital age. Psychological Inquiry, 31(3) 195-223. 10.1080/1047840X.2020.1820214

Hackman, H.W. (2005). Five essential components for social justice education. Equity \& Excellence in Education, 38, 103-109. DOI: 10.1080/10665680590935034

Hantzopoulos, M. (2016). Restoring Dignity in Public Schools. Teachers College Press.

Khran, E. (2019). Storytelling, poetry, writing, and the art of metaphor. In T. Heinonen, D. Halonen, \& E. Krahn (Eds.), Expressive Arts for Social Work and Social Change (pp. 76104). Oxford University Press.

Kreniske, P. (2017a). Developing a culture of commenting in a first-year seminar. Computers in Human Behavior, 72, 724-732. 10.1016/j.chb.2016.09.060

Kreniske, P. (2017b). How first-year students expressed their transition to college experiences differently depending on the affordances of two writing contexts. Computers and Composition, 45, 1-20. 10.1016/j.compcom.2017.07.001

Kuh, G. D., \& Association of American Colleges and Universities. (2008). High-impact educational practices: What they are, who has access to them, and why they matter. Association of American Colleges and Universities.

Lambert, J. (2013). Digital storytelling: Capturing lives, creating community (4th ed.). Routledge.

Lenette, C, Cox, L. \& Brough, M. (2015). Digital storytelling as a social work tool: Learning from ethnographic research with women from refugee backgrounds. The British Journal of Social Work, 45(3), 988-1005.

Lopez, F.A. (2017). Altering the trajectory of the self-fulfilling prophecy: asset-based pedagogy and classroom dynamics. Journal of Teacher Education 68(2) 193-212. doi.org/10.1177/0022487116685751

McNamee, S. (2016). The social study of childhood. Palgrave Macmillan.

Moore, R, Vitale, D. \& Stawinoga, N. (2018). Insights in Education and Work. The digital divide and educational equity: A look at students with very limited electronic devices at home. Act for Center for Equity in Learning.

National Center for Education Statistics (2020). The condition of education 2020 (NCES 2020144), undergraduate retention and graduation rates. https://nces.ed.gov/fastfacts/display.asp?id=40

New York City College of Technology (2018). Fact sheet (2018-2019). http://www.citytech.cuny.edu/about-us/docs/facts.pdf.

Noguera, P. A. (2002). Beyond size: The challenge of high school reform. Educational Leadership, 59(5) 60-63.

NSC Research (2019). Persistence \& retention. National Student Clearinghouse Research Center. https://nscresearchcenter.org/snapshotreport35-first-year-persistence-and-retention/. 
Polkinghorne, D. E. (1988). SUNY series in philosophy of the social sciences. Narrative knowing and the human sciences. State University of New York Press.

Polkinghorne, D.E. (1995). Narrative configuration in qualitative analysis. International Journal of Qualitative Studies in Education. 1(8) 5-23. 10.1080/0951839950080103

Purcell, K., Buchana, J., \& Friedrich, L. (2013). The impact of digital tools on student writing and how writing is taught in schools. The Pew Center: Internet and Technology. https://www.pewresearch.org/internet/2013/07/16/the-impact-of-digital-tools-on-studentwriting-and-how-writing-is-taught-in-schools/

Ravitch, D. (2010). The death and life of the great American school system: How testing and choice are undermining education. Basic Books.

Ravitch, D. (2013). Reign of error: The hoax of the privatization movement and the danger to America's public schools. Random House.

Reamer, F. G. (2013). "Social Work in a Digital Age: Ethical and Risk Management Challenges" Faculty Publications. 391. https://digitalcommons.ric.edu/facultypublications/391

Ribera, A., Miller, A. \& Dumford, A. (2017). Sense of peer belonging and institutional acceptance in the first year: The role of high-impact practices. Journal of College Student Development. 58. 545-563. 10.1353/csd.2017.004

Rodriguez, N., Myers, H. F., Morris, J. K., \& Cardoza, D. (2000). Latino college student adjustment: Does an increased presence offset minority-status and acculturative stresses? Journal of Applied Social Psychology, 30(7), 1523-1550. 10.1111/j.1559-1816. 2000.tb02534.x

Rolón-Dow, R. (2011) Race(ing) stories: digital storytelling as a tool for critical race Scholarship. Race Ethnicity and Education, 14:2, 159-173, DOI: 10.1080/13613324.2010.519975

Rosen, J. R., \& Smale, M. A. (2015, January). Open digital pedagogy = critical pedagogy. Hybrid Pedagogy. https://hybridpedagogy.org/open-digital-pedagogy-critical-pedagogy/

Sandelowski, M. (1991). Telling stories: narrative approaches in qualitative research. The Journal of Nursing Scholarship, 23(3), 161-166. 10.1111/j.1547-5069. 1991.tb00662.x

Schiff, B. (2014). Rereading personal narrative and the life course. New Directions for Child and Adolescent Development, 145.

Stewart, K.D. \& Ivala, E. (2017). Silence, voice, and "other languages": Digital storytelling as a site for resistance and restoration in a South African higher education classroom. British Journal of Educational Technology, 48(5) 1164-1175. doi.org/10.1111/bjet.12540

Strauss, A. and Corbin, J. (1994) Grounded Theory Methodology-An Overview. In: Norman, K.D. and Vannaeds, S.L.Y., Eds., Handbook of Qualitative Research, Sage Publications, Thousand Oaks, 22-23.

Strauss, A., \& Corbin, J. (1998). Basics of Qualitative Research: Techniques and Procedures for Developing Grounded Theory. Thousand Oaks, CA: Sage Publications, Inc.

Tinto, V. (2012). Completing college: Rethinking institutional action. The University of Chicago Press.

Tyton Partners (2017). Finding a fit: The evolution of student-centered financial aid https://tytonpartners.wpengine.com/library/finding-fit-evolution-student-centeredfinancial-aid/

Vasudevan, L. (2006). Making known differently: Engaging visual modalities as spaces to author new selves. E-Learning and Digital Media, 3, 2, 207-216. https://doi.org/10.2304/elea.2006.3.2.207

Walton, G. \& Cohen, G. (2011). A brief social-belonging intervention improves academic and health outcomes of minority students. Science, 331(6023), 1447-1451. 
Wertsch, J. V. (1991). Voices of the mind: A sociocultural approach to mediated action. Harvard University Press.

\section{Notes on Contributors}

Mery F. Diaz, DSW is an Associate Professor of Human Services Department at the New York City College of Technology, CUNY. Her research focuses on minoritized and racialized student school experiences. She is a long-time faculty participant of City Tech's First Year Learning Community program, she is co-editor of Narrating Practice with Children and Adolescents (Columbia University Press, 2019), and is on the editing board of Affiliation: Journal of Women and Social Work.

Sandra Cheng, Ph.D., is an Associate Professor of art history at New York City College of Technology, CUNY. Her research interests include caricature; drawings and studio practice; and intersections of early modern art and science. She has served as a Faculty Leader for City Tech's First Year Learning Community program, and she continues to teach FYLC courses.

Karen Goodlad, CSW is an Associate Professor of Hospitality Management at New York City College of Technology, CUNY. Her work involves a variety of subjects ranging from beverage management to bringing high impact practices to more classrooms. She serves on the steering committee for the college's First Year Experience program and is as a Faculty Leader for City Tech's First Year Learning Community program and teaches FYLC courses.

Jennifer Sears, MFA is an Associate Professor of English at New York City College of Technology, CUNY. She is as a Faculty Leader for City Tech's First Year Learning Community program and is a dedicated FYLC instructor. Also, a fiction writer, she received creative writing fellowships in 2018 from the National Endowment for the Arts and the New York Foundation for the Arts.

Philip Kreniske, Ph.D. is a Postdoctoral Research Fellow with the HIV Center for Clinical and Behavioral Studies at the New York State Psychiatric Institute and Columbia University. His research focuses on health and adolescent transitions in the U.S. and sub-Saharan Africa. He earned his doctorate from the CUNY Graduate Center where he created a digital network, and then studied the ways that first-generation and low-income students used the network to generate a system of support in their transition to college.

Ashwin Satyanarayana, Ph.D. is an Associate Professor with the Department of Computer Systems Technology, New York City College of Technology, CUNY, where he serves as a Faculty Leader for City Tech's First Year Learning Community program. He is also currently serving as Chair Elect of the ASEE (American Society of Engineering Education) Mid-Atlantic Conference.

Manuscript received October 12, 2020

Final revision received February 1, 2021

Accepted February 3, 2021 